\title{
A UTAUT Evaluation of WhatsApp as a Tool for Lecture Delivery During the COVID-19 Lockdown at a Zimbabwean University
}

\author{
Vusumuzi Maphosa ${ }^{1}$, Bekithemba Dube ${ }^{2} \&$ Thuthukile Jita $^{2}$ \\ ${ }^{1}$ Department of Information Communication Technology and Services, Lupane State University, Zimbabwe \\ ${ }^{2}$ School of Educational Studies, University of the Free State (UFS), South Africa \\ Correspondence: Vusumuzi Maphosa, Department of Information and Communication Technology and Services, \\ Lupane State University, $3^{\text {rd }}$ Floor CBZ Building, Fife Street and $10^{\text {th }}$ Ave, Bulawayo, Zimbabwe.
}

Received: June 3, 2020

doi:10.5430/ijhe.v9n5p84
Accepted: July 4, 2020

Online Published: July 7, 2020

\begin{abstract}
Focusing through the lens of the (COVID-19) lockdown which was enforced on the $30^{\text {th }}$ of March 2020, it became apparent that students from rural resource-constrained educational institutions had to adapt to sustainable online learning platforms from traditional content delivery. WhatsApp a social networking app, but due to its low data consumption, it became a de-facto teaching and learning tool for Lupane State University (LSU) students in Zimbabwe. Prior studies have focused on the use of WhatsApp as an alternative lecture delivery platform but very few have evaluated its role as the sole platform for lecture delivery. With no government or institutional support for data acquisition, students failed to utilise other e-learning platforms that were in place due to exorbitant data costs. This study seeks to evaluate the success of WhatsApp mediated teaching and learning at LSU during the COVID-19 pandemic. This was a randomized evaluation of weekly lecture delivery through WhatsApp to LSU students. A questionnaire based on the Unified Theory of Acceptance and Use of Technology's main constructs was delivered to 200 students that were randomly selected. The results revealed that student's attitudes, behavioral intention of using WhatsApp for learning as well as the platform's usefulness were rated highly, implying high adoption. The positive perceptions suggest that it would be easy for the institution to formally integrate the platform to augment traditional lecture delivery or for use during an event that disrupts traditional face-to-face lecture delivery. Results revealed that WhatsApp can support $21^{\text {st }}$ century learning through autonomous, collaborative and learner centred education.
\end{abstract}

Keywords: WhatsApp, COVID-19, UTAUT model, behavioral intention, mobile learning, collaborative learning, $21^{\text {st }}$ century learning

\section{Introduction}

All major economies of the world have been hit by the outbreak of the acute respiratory syndrome coronavirus 2 (SARS-COV-2), the virus that causes COVID-19, which is highly infectious and at the time of writing this paper over one million people had contracted the disease and killed over 100000 people globally (Baldwin \& di Mauro, 2020). The initial outbreak was recorded in Wuhan province in China and its first death was on 9 January 2020 and then it spread quickly across the globe, with the major economies being the hardest hit (Odendahl \& Springford, 2020). This resulted in many governments implementing measures that restricted gathering and movement of people to contain the spread of the disease commonly known as social distancing (Odendahl \& Springford, 2020). The outbreak forced governments to shut down most businesses and other institutions such as schools. The major industrialised countries have entered the accelerating phase of their 'epidemiological curve', with Italy being the epicentre (Baldwin \& di Mauro, 2020). The outbreak of the COVID-19 virus has disastrous impact on education and every other sector of the global economy if not threatening humanity at large. As higher education looks through the current lens of or post COVID-19, it has become apparent that more adaptive strategies have to be pursued to embrace off-campus learning to ensure continuous learning when face-to-face delivery is not possible. In Zimbabwe online learning is emerging as a necessity to meet the challenges posed by the COVID-19 outbreak as well as taking advantage of the enormous advances in information technology.

Today's information technology has influenced every sphere of human life and this has not spared the field of education, where traditional face-to-face content delivery is being challenged by virtual and distance learning. As the Internet and related technologies have been embraced at a global scale, educational institutions must cease and 
exploit their enormous potential for supporting continuous learning beyond the physical classroom. The purpose of electronic learning (e-learning) is to ensure that learning is accessible and continues beyond the limitations of time, place and space. In this study e-learning refers to what Mwakyusa (2016) defined as the conducting of learning activities across various Information and Communication Technology (ICT) platforms such as computers, software and internet. Amry (2014) posited that the purpose of e-learning is to deliver educational content beyond the classroom walls allowing the lecturer and the student to interact beyond distance and time constraints. The rising costs of material such as printed textbooks and enrolment of working students has prompted educational institutions to invest in e-learning. Yulius and Hartanto (2016) noted that e-learning enabled institutions to reduce costs and increase the availability of education through utilisation of a variety of digital technologies. Teaching and learning has also transformed over time and through the adoption of digital technologies, Amry (2014) states that it has become ubiquitous and increasingly challenging the traditional face-to-face delivery.

The widespread use of smartphones and tablets would increase data traffic in sub-Saharan Africa 20-fold, from 2013 to 2019 (GSMA, 2014). Benjamin (2011) noted an impressive increase in smartphone ownership by university students in South Africa over the past years. La Hanisi et al. (2018) noted that students have made smartphones an inseparable part of themselves and spend most of their time accessing social media chatting and sharing photos and videos, playing games and reading news. Amry (2014) points that the introduction of smartphones has promoted student centred discussion forums which results in the construction of new knowledge which is shared within the group.

One major impediment hampering the implementation of e-leaning in developing countries is lack of access to laptops and computers by students at their homes. The smartphone has been described as the most common "personal computer" for developing countries which provides real time communication and instant access to a wide variety of multi-media information (Boulos et al, 2011). The mobility and interactivity offered by smartphones to students is viewed as the future for education as it promotes lifelong learning which can be undertaken anywhere and everywhere (Khubyari, 2016; Amry, 2014; Ali Ta'amneh, 2017). Robles et al. (2019) noted mobile learning (m-learning) provides learners with unlimited opportunities to learn in their natural and real environments, describing this experience as authentic interaction which is more effective than traditional classrooms. From these studies it is evident that $\mathrm{m}$-learning is the future of education with its ability to facilitate everywhere and anywhere learning at a critical time such as the global lockdown due to COVID-19.

Social networking sites have become common among young people and provide an opportunity to accelerate access to education in developing countries because of their affordability and availability (Gasaymeh, 2017). One such application is WhatsApp, a smartphone app which was initially developed for instant communication through message exchange. Church and de Oliveira (2013) described WhatsApp as a smartphone-internet based application that allows users to exchange instant messages and multi-media files at low cost. Today's students are hyper active and want to communicate instantly, as such WhatsApp has become one of the most popular apps as it allows cheap and instant sharing of ideas in a faster and easier way (Mistar \& Embi, 2016). Cetinkaya (2017) concurs by highlighting that WhatsApp is one of the most common instant messaging applications which operates on smartphones. Statistics show that by mid-2018 WhatsApp users sent over 65 billion messages per day and an average of 29 million messages per minute (BusinessofApps, 2020). This has made WhatsApp to be very common in most developing countries as it is freely available, easy to use, fast, convenient and offers a reliable personal mode of communication.

One feature which has made WhatsApp to be very useful among university students worldwide is its ability to create groups within the application which allows students to collaborate on tasks and communicate from anywhere and at any time (Bere, 2013; Yeboah \& Dominic, 2014). The administrator of the group can add other members such as lecturers and students. Students can share their thoughts and opinions through text, voice notes, and videos through WhatsApp (Mistar \& Embi, 2016). Lecturers can deliver voice notes and explain some concepts to their students. Members of the group can collaboratively participate and engage in a discussion on a selected topic and each member can pose a question to the lecturer or to other members instantly. One important benefit of using WhatsApp to students is that it enables teaching and learning to occur through their most personal gadgets in a fun-based environment and conviniently sharing and accessing information in real time (La Hanisi et al., 2018).

For users to adopt a system, it must be easy, simple and demands less effort. Mistar and Embi (2016) pointed out that once an individual has a smartphone with internet access, using WhatsApp is a very simple operation which does not require meaningful effort. This was corroborated by Church and De Oliveira (2013) who noted that WhatsApp was simple, accessible, efficient and cheap compared to other tools which can support teaching and learning. Gon and 
Rawekar (2017) observed that the use of WhatsApp on smartphones resulted in eye strain, message flooding and the burden to keep track of messages. The observations by Ngambi and Hardman (2004) and Rambe and Bere (2012) that previous studies on the adoption of m-learning in South Africa barely focused on previously disadvantaged students motivated this study to focus on students studying at a rural and resource constrained institution in Zimbabwe.

\section{Background}

Since its establishment, Lupane State University (LSU) has developed its information and communication technology infrastructure and upgraded its Wi-Fi to support the growing student and staff populations. Despite considerable progress in the use of technology, the level of e-learning adoption is still very low by many institutions in developing countries (Mwakyusa, 2016). In 2016, LSU adopted Moodle as its official e-learning platform to support its pedagogical needs in response to escalating costs of printing material and also responding to the needs of learners in adopting technology. Additionally, student enrolment figures have continued to increase while there has been no increase in lecture rooms and other facilities. Moodle was chosen mainly because it is free, easy to use and can support offline usage. The platform allows lecturers to create content that allows students to creatively construct knowledge collaboratively. To ensure utilisation, training workshops were conducted for academic staff and also creating awareness among university students. Statistics revealed that only $30 \%$ of the lecturers were using the platform. To improve usage statistics, Moodle usage could be made mandatory and included in the lecturer's performance evaluation. There is need to reconsider the entire eco-system and offer incentives from content writers to content evaluators. Students and staff utilised the institution's computer network and Wi-Fi to access Moodle.

The outbreak of COVID-19 has seen educational institutions suspending all face-to-face learning modes and adopting online methods. A recent survey revealed that the cost of one giga byte of data in Zimbabwe was the highest in the world (TechZim, 2019) and this limits student access to other e-learning platforms which demand more data, therefore WhatsApp became the de-facto online learning platform for the institution. Research has shown that costs of broadband data (Alliance for Affordable Internet [A4AI], 2016). A survey conducted in 2014, revealed that 11\% of Zimbabweans owned a computer or laptop (Zimstats, 2014). This shows that the majority of the population only connects to the internet through their mobile devices whose ownership was over 90\% (TechZim, 2019).

Prior studies that have been conducted have evaluated the use of WhatsApp in extending and reinforcing content that was learnt through face-to-face learning or other video conferencing technologies. For a rural institution like LSU, it became impossible for students to use the official e-learning platform as it required substantial amount of data. Zimbabwean universities did not provide students with free laptops or data in comparison to their South African counterparts who distributed laptops and offered free data in order to support off-campus learning and combat the spread the COVID-19, with the University of Fort Hare availing 12000 laptops (News24, 2020). LSU adopted WhatsApp for learning due to its popularity with students, this was similar to findings by Yeboah and Dominic (2014) who highlighted that $96 \%$ of university students used this app extensively. There are very few studies that have been conducted in Zimbabwe to evaluate the use of social media tools such as Facebook and WhatsApp to support teaching and learning at a university. This study provides insight and will be helpful in building literature in the context of developing countries with limited resources and the results could be used to influence wider adoption of e-learning technologies by educational institutions.

\section{Aim}

This study seeks to determine student acceptance and intentions to utilise WhatsApp as an e-learning platform during the COVID-19 outbreak.

\section{Research Questions}

The study sought to answer the following research questions:

(a)What are the behavioural intentions and attitudes of students towards using WhatsApp?

(b)What are the students' perceptions on the use of WhatsApp for their studies?

\section{Literature}

The information technology revolution has affected every facet of human life and its impact has greatly influenced education delivery. Institutions must innovatively deploy such technology to complement face-to-face teaching and learning and as an alternative when it is not feasible to deliver conventional learning. The Singapore government closed universities and most businesses after detecting the first outbreak of the COVID-19 on the $4^{\text {th }}$ of February 2020 in the country, after which a national lockdown was declared to combat the pandemic (Quah, 2020). 
Thereafter, many countries began to adopt similar strategies. This also came at a time when other proponents of educational technology had challenged higher educational institutions to model their teaching and learning strategies around the enabling digital technologies (Popenici \& Kerr, 2017). The implication on pedagogies posed by the inclusion of technology in supporting higher education is worth investigating (La Hanisi et al., 2018). Robles et al. (2019) pointed out that university students had found the ubiquity of technological devices, mobilty and connectivity as great tools for supporting their academic activities. Studies have shown that students prefer to learn through social networking sites than face-to-face classroom as they enjoyed the collaboration and the continuous learning offered through technology (Amry, 2014; Ali Ta'amneh, 2017). Instant messaging systems have gained much popularity and this has seen higher education institutions in developed countries integrating these into their curricula (So, 2016).

One major challenge with the using traditional e-learning systems such as Moodle, Blackboard, Claroline and Sakai among others is that they require substantial training. One observation with WhatsApp is that it requires little or no training. This was corroborated by Bouhnik and Deshen (2014) who stated that WhatsApp was the only technology so far which had found itself in the classroom without any training offered to teachers, students and administrators. The traditional e-learning systems require a stable broadband connection and access to a computer and a laptop which is a major hindrance during the COVID-19 lockdown. Most students do not have access to laptops and desktops as confirmed by a survey by Zimstats (2014) which revealed that about $11 \%$ of the population has access to one of the devices, and this limits access to Wi-Fi at their homes. This makes the use of traditional e-learning platforms off campus unachievable. During this lockdown, universities should utilise off-campus learning systems which will be effectively used by students, considering data costs and accessibility and for a rural and resource constrained university, WhatsApp would be more ideal. Students in most South African universities got free 30GB of data from the mobile network operators to support e-learning during the COVID-19 lockdown (Wits, 2020). Barhoumi (2015) highlighted that it was easier to deploy WhatsApp in resource constrained environments as it offered technical advantages such as low cost, easy to use and easy access. Ahad and Lim (2014) confirmed that the popularity of WhatsApp was due to its low cost, ease of use, and unlimited instant messaging. Rambe and Crispen (2013) reported that off-campus students who had limited access to library resources due to data costs relied on WhatsApp to accomplish educational tasks after hours. According to Zimstats (2014), only 4.4\% of the Zimbabwean population had a fixed telephone landline and this has a huge impact on citizens who have Wi-Fi connections at their homes.

E-learning provides students with an opportunity to gain knowledge through experiential learning, where they share opinions, debate on particular concepts as they build consensus on some theory or concept (Amry, 2014, Robles et al., 2019). La Hanisi et al. (2018) concluded that apps provide an enormous potential to support teaching and learning through facilitating access to resources that allow students to be accountable for their individual learning through their creativity and autonomy Rambe and Crispen (2013) argued that the academic potential of smartphones to support m-learning has not been fully researched, and therefore this study builds knowledge on the domain. It is evident that m-learning has great potential in transforming higher education and Nikou and Economides (2017) contended that mobile technologies offered new possibilities for lecture delivery and student assessment.

Many theories have been developed to predict an individual's adoption of a certain technology over the years and these had some limitations. Venkatesh et al. (2003) integrated these individual theories into the Unified Theory of Acceptance and Use of Technology (UTAUT) model whose main constructs are performance expectancy, effort expectancy, social influence, facilitating conditions, behavioral intention and usage behavior as shown in figure 1 . The evaluation of the UTAUT model revealed that it could predict with certainty $70 \%$ of the user's intention to use a particular technology (Venkatesh et al., 2003). In their study, Moran et al. (2010) used UTAUT to predict student's intentions to use smartphones for learning, the scholars noted that performance expectancy and effort expectancy were key in determining the students' intentions and together with the facilitating conditions predicted the actual usage. In similar studies, Tosuntas et al. (2015) and Hui Hsu (2012) concluded that performance expectancy, effort expectancy and social influence were key determinants of behavioural intention. Another study by Sumak et al. (2010) underscored the importance of social influence in predicting the students' behavioral intention to use Moodle.

One major social networking application that has greatly affected the lives of young people is WhatsApp and Cetinkaya (2017) believes that it will have the same impact on their education. Echeverria et al. (2011) posited that many higher education institutions had recently adopted WhatsApp to enhance information sharing, communication and collaboration through forums amongst the students. Effective teaching and learning is achieved when the lecturer and the students are effectively interacting, and Khubyari (2016) noted that WhatsApp allows for regular interaction between the lecturer and students thus creating a good rapport. Related to the current lockdown, Chipunza (2013) asserted that WhatsApp was a vital tool that could bridge educational access challenges as it allowed university 
students to share information. Rambe and Crispen (2013) established that the adoption of WhatsApp at a university redressed information access asymmetries as it allowed students from poor backgrounds to ubiquitously access educational content through their phones.

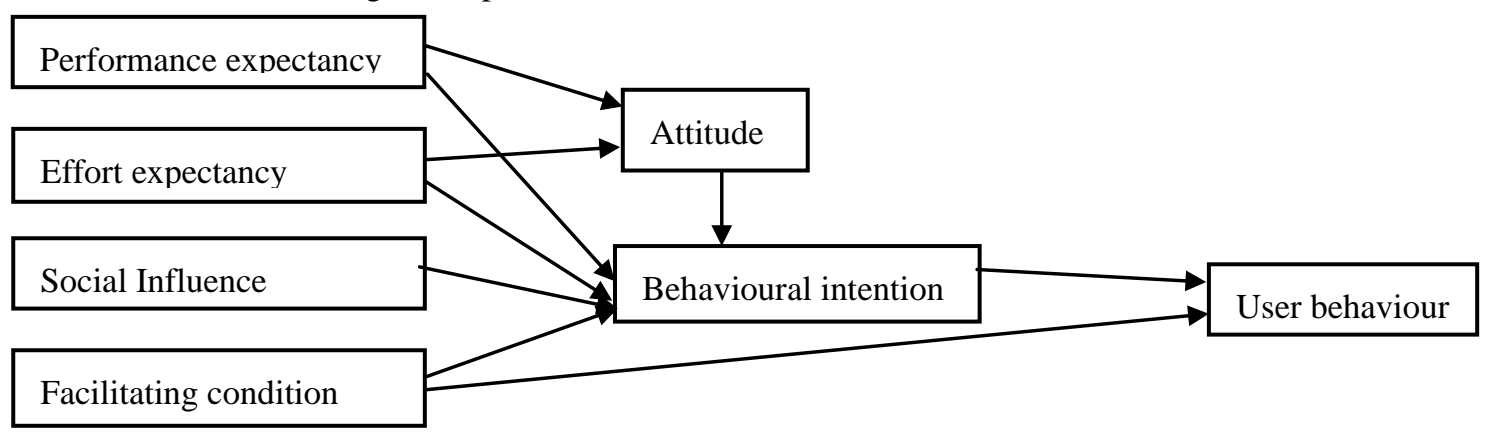

Figure 1. Proposed theoretical framework ((Source: Adapted from Venkatesh et al. 2003)

After exploring the advantages offered by WhatsApp to university students in India, Patil et al. (2015) recommended integratimg the platform into the pedagogical processes as they posited that the platform allowed students to easily create and share information. This allows students to have educational information at the fingertips and the platform allows the lecturer-to-student and student-to-student communication in real time as well as asynchronously. Barhoumi (2015) established that the use of WhatsApp had positively impacted the students learning performance through evaluating their performance and attitudes in adopting the platform. A study by Amry (2014) revealed that an experimental group whose lectures were delivered using WhatsApp performed better than the control group which used conventional face-to-face learning with a t-test difference of 0.05 alpha level. A similar study in Saudi Arabia by Fattah (2014), revealed that an experimental group that was studying English language using WhatsApp performed better in their writing skills compared to a control group that studied using the prescribed textbooks. Upon examining conversations between students in a WhatsApp group, Rambe and Crispen (2013) reiterated that the platform provided space for academic discourse between the students.

Another study by Gachago et al. (2015) found that WhatsApp helped lecturers to facilitate and co-ordinate learning and could blur differences between on-campus and off-campus among the learners. Bouhnik and Deshen (2014) concluded that WhatsApp created a conducive learning environment among learners through creating an atmosphere that supported interaction, sharing of content and intense collaboration among the peers. Ali Ta'amneh (2017) reported that WhatsApp offered a flexible way for students to interact amongst themselves and with their lecturers when compared to traditional lecture delivery. Similarly, Diaz (2015) noted that the interaction amongst the students promoted formal learning and the use of WhatsApp allowed students to access information on the move, anytime and anywhere.

Considerable effort has been put to transform educational pedagogy from teacher-centric to student-centred. Mistar and Embi (2016) reported that WhatsApp supported student-centred learning by supporting their active involvement in determining how and when they learn. In a case study on university students in South Africa, Rambe and Bere (2013) reported that WhatsApp could transform higher education as it provided an alternative space for students to engage and collaborate when doing their on-campus and off-campus tasks. The students further noted that the platform was easy to use, fun and had positive intentions to use WhatsApp for formal learning. Ali Ta'amneh (2017) also revealed that WhatsApp positively affected the student's perception to adopt the platform as it enabled them to connect with their peers and learn collaboratively at any time. Kushwaha and Jhawar (2018) noted that WhatsApp positively impacted learning as it provided rich multi-media content which was accessible to the students and learning could take place at anytime and anywhere. Another study conducted by Su (2016) in Hong Kong highlighted that students had a positive perception on the use of WhatsApp in lecture delivery, this was regardless of their prior experience with its integration in higher education. It is evident that the implementation of WhatsApp to support teaching and learning during the COVID-19 lockdown is more feasible as it does not require training of the staff and students, no administrative and costly infrastructure.

Although WhatsApp integration has great impact in supporting education, Cetinkaya (2017) noted that institutions had to be cautious as studies revealed that some students lost attention and used improper language and had relations extending beyond academic discourse. A study by Yeboah and Dominic (2014) in Ghana revealed some negative impact on the usage of WhatsApp such as spelling errors and grammatical errors in the construction of sentences. 
The limitations of smartphones like short battery life, small screens and limited input capability were noted among some of the impediments on integrating WhatsApp in education (So, 2016).

\section{Study Design and Methods}

The study adopted a survey research design through the use of the UTAUT to examine the acceptance of WhatsApp as a tool to support e-learning at LSU during the COVID-19 outbreak when the majority of the students could not access the official university e-learning platform due to unaffordable data costs. UTAUT is considered as one of the most significant models because it was developed based on the dimensionalities extracted from the preceding models that had been used to explain user behaviour towards acceptance of a new information system (Riaz \& Adnan, 2016, Vankatesh et al., 2003). The main constructs of the UTAUT model that have an impact on the students' intention to use WhatsApp are performance expectancy, effort expectancy and social influence. The model includes four moderators: age, gender, experience and voluntariness of use which play a part in determining the user's acceptance of a new technology. Ali, Kate and Xiaohui (2013) pointed out that e-learning implementation is not simply applying technology but it also involves evaluating the social and behavioral beliefs of the target population. Another study conducted by Gasaymeh (2017) established that students had positive perception and attitude towards the integration of WhatsApp in their educational curricula.

\subsection{Sample}

The study participants were undergraduate and postgraduate students from LSU during the 2019-2020 academic year. The purpose of the research was outlined to the participating students and its voluntary nature allowed students to withdraw from the study at any time. The data collection process dealt with issues of participants' consent, confidentiality and anonymity. Data was collected from 200 students using random sampling through an online questionnaire that was developed using constructs from the UTAUT model by Venkatesh et al. (2003) as shown in table 1. A five-point Likert scale was used where 1 represented (strongly disagree) to 5 (strongly agree) with 3 representing neutral. Eight-two participants who successfully completed the questionnaire, giving a response rate of $41 \%$. Of the 82 participants, $58.5 \%$ being female while $41.5 \%$ were male. Regarding their level of study, $43.9 \%$ were undergraduate while $56.1 \%$ were postgraduate students. In terms of ages, $28 \%$ were between $18-24$ years old, $37.8 \%$ were between $25-30$ years, $24.4 \%$ were between $31-40$ years while $9.8 \%$ were over 40 years.

Table 1. Variables of the research model

\begin{tabular}{|c|c|c|}
\hline Construct & Meast & tem \\
\hline \multirow[t]{3}{*}{ Performance Expectancy } & i. & Using WhatsApp improves my learning \\
\hline & ii. & Using WhatsApp enhances my learning motivation \\
\hline & iii. & WhatsApp increases my interests and motivation in lessons \\
\hline \multirow[t]{3}{*}{ Effort expectancy } & i. & I would find WhatsApp is easy for me to use \\
\hline & & $\begin{array}{l}\text { WhatsApp is new to me and I am not comfortable using it, I could } \\
\text { e any problem very quickly }\end{array}$ \\
\hline & iii. & I would find WhatsApp useful in my university studies \\
\hline \multirow[t]{3}{*}{ Social Influence } & i. & I think that using WhatsApp is fashionable \\
\hline & ii. & My peers and lecturers think that I should use WhatsApp \\
\hline & iii. & I use WhatsApp because people around me use it. \\
\hline \multirow[t]{3}{*}{ Facilitating Condition } & i. & I have the resources necessary to use WhatsApp \\
\hline & & $\begin{array}{l}\text { I think the availability of the lecturer on WhatsApp fits well with } \\
\text { vay I like to learn }\end{array}$ \\
\hline & iii. & I may not follow the lecture due to message flooding my phone \\
\hline \multirow[t]{3}{*}{ Behavioral Intention } & i. & I intend to use WhatsApp in my future learning activities \\
\hline & ii. & Using WhatsApp is a good idea \\
\hline & iii. & Whenever it is possible, I will use WhatsApp for learning \\
\hline
\end{tabular}




\subsection{Results and Discussion}

The students evaluated the impact of WhatsApp by rating 15 constructs in table 1 using a 5-point Likert scale. When measuring the reliability of the constructs, a high value (cronbach alpha $=0.849$ ) was realised indicating acceptable internal consistency of the varaibles. WhatsApp usage was moderately high as students reported an average mean of 3.79 and standard deviation of 0.87 .

Following UTUAT constructs, WhatsApp was evaluated for effort expectancy and at least $77 \%$ of the students agreed that WhatsApp offered them an opportunity to learn during the COVID-19 lockdown. This is consistent with findings by Bansal and Joshi (2014), and Pana, et al., (2013) who observed that $75 \%$ of the students agreed that WhatsApp increased their motivation and willingness to learn. The adoption of any technology is dependent on its easy of use, in this study, $80 \%$ of the students concurred that WhatsApp was easy to use and convenient. Regarding social influence, $74.4 \%$ of the students noted that learning with WhatsApp was fashionable and this is in line with work by Andujar (2016) and Gon and Rawekar (2017) who established that WhatsApp enabled students to access resources independently, learn from anytime and anywhere a requirement for 21 st century learning and teaching. Regarding social influence, $54.9 \%$ of the students revealed that they were using WhatsApp because their peers were using it. This percentage is not high as the students had already started using WhatsApp.

High adoption rates are related to facilitating conditions, as $71.9 \%$ of the students highlighted that they could solve any problem related to WhatsApp on their own and very quickly. Other e-learning platforms require significant amounts of data at exorbitant costs, in this study $74.4 \%$ of the students agreed that WhatsApp offered a low cost means of learning and this is consistent with findings by Bouhnik and Deshen (2014) who established that low cost, simplicity and privacy were major drivers for WhatsApp adoption. One factor that influenced WhatsApp adoption that was noted by $62.5 \%$ of the students was lecturer availability, and this is consistent with findings by Bouhnik and Deshen (2014) and Gon and Rawekar (2017) who concluded that lecturer availability was key as it allowed learning to take place all the time. The behavioral intention to use WhatsApp was evaluated based on easy access to lecture material, and 78\% of the students agreed that WhatsApp provided a simple way to access learning content and this was critical during this lockdown. Regarding future intentions to use the platform, $76.8 \%$ of the students indicated that they would want to use WhatsApp in the future. This is consistent with work by Mistar and Embi (2016) whose study established that all the students were eager to use WhatsApp for their learning in the future.

When measuring performance expectancy, $70 \%$ of the students agreed that WhatsApp enhanced, motivated and engaged them in their learning, this was congruent with the views of Barry, Murphy and Drew (2014) who contended that the use of WhatsApp improved student engagement which led to better learning outcomes. Some technical disadvantages were noted by $65 \%$ of students in this study which related to message flooding and this was similar to findings by Gon et al. (2017) who lamented the use of small screen devices which resulted in eye strain and message flooding during a lecture that was delivered through WhatsApp.

\section{Conclusion}

This study demonstrated how WhatsApp was useful in supporting teaching and learning when other official University e-learning platforms failed due to data constraints and device limitations during the COVID-19 lockdown. The findings revealed that the students' attitudes, behavioral intention as well as the platform's usefulness were high which revealed high adoption. The positive perceptions of the students suggest that it would be easy for the institution to formally adopt and integrate the platform to support teaching and learning or used when the traditional face-to-face lecture delivery is not available. This is consistent with earlier research which highlighted that WhatsApp offered technological and pedagogical advantages which could support learning in developing countries with limited infrastructure and resources. The findings revealed that WhatsApp supported $21^{\text {st }}$ century learning skills as it was rich in collaborative, independent and ubiquitous learning. For more conclusive evidence, there is need to use statistical tests to compare results between students taught through WhatsApp and those taught using traditional approach to ascertain the benefits of the application. This work provides evidence for policymakers to consider ICT infrastructure development and integrating technology in the class as well as laying a foundation for future research.

\section{References}

A4AI. (2016, February). The 2015-16 Affordability Report. Retrieved from A global coalition working to make broadband affordable for all: https://a4ai.org/affordability-report/report/2015/

Abdekhoda, M., Dehnad, A., Mirsaeed, G., \& Gavgani, G. (2016). Factors influencing the adoption of E-learning in Tabriz University. Medical Journal of the Islamic Republic of Iran (MJIRI), 30(457), 1-7. 
Ahad, A. D., \& Lim, S. M. (2014). Convenience or nuisance?: The 'WhatsApp'dilemma. Procedia Social and Behavioral Sciences, 155, 189-196. https://doi.org/10.1016/j.sbspro.2014.10.278

Ali Ta'amneh, A. (2017). The Effect of Using WhatsApp Messenger in Learning English Language among University Students. International Research in Education, 5(1), 143-151. https://doi.org/10.5296/ire.v5i1.10801

Ali, T., Kate, H., \& Xiaohui, L. (2013). Factors Affecting Students' Acceptance of E-learning Environments in Developing Countries: A structural Equation Modeling Approach. International Journalof Information and Education Technology, 3(1).

Amry, B. A. (2014). The impact of WhatsApp mobile social learning on the achievement and achievement of female stdents compared with face to face learning in the cllassroom. European Scientific Journal, 10(22), 116-136.

Andujar, A. (2016). Benefits of mobile instant messaging to develop ESL writing. System, 62, 63-76. https://doi.org/10.1016/j.system.2016.07.004

Annamalai, N. (2017). Uing WhatsApp to extend learning in a blended learning environment. Teaching English with Technology, 19(1), 3-20.

Asterhan, C. S., \& Rosenberg, H. (2015). The promise, reality and dilemmas of secondary school teacher-student interactions in Facebook: The teacher perspective. Computers \& Education, 85, 134-148. https://doi.org/10.1016/j.compedu.2015.02.003

Baldwin, R., \& di Mauro, W. B. (2020). Introduction. In R. Baldwin, \& W. B. di Mauro, Mitigating the COVID Economic Crisis: Act Fast and Do Whatever It Takes (pp. 1-24). London: CEPR Press.

Bansal, T., \& Joshi, D. (2014). A study of students' experiences of mobile. learning. Global Journal of Human-Social Science, 14(4), 91-102.

Bansal, T., \& Joshi, D. (2014). A study of students' experiences of mobile learning. Global Journal of Human-Social Science: H Interdisciplinary, 14(4), 26-33.

Barhoumi, C. (2015). The Effectiveness of WhatsApp Mobile Learning Activities Guided by Activity Theory on Students' Knowledge Management. Contemporary EducationalTechnology, 6(3), 221-238. https://doi.org/10.30935/cedtech/6151

Barry, S., Murphy, K., \& Drew, S. (2015). From deconstructive misalignment to constructive alignment: Exploring student uses of mobile technologies in university classrooms. Computers \& Education, 81, 202-210. https://doi.org/10.1016/j.compedu.2014.10.014

Bere, A. (2013). Using mobile instant messaging to leverage learner participation and transform pedagogy at a South African University of Technology. British Journal of Educational Technology, 44(4), 544-561. https://doi.org/10.1111/bjet.12057

Bouhnik, D. (2014). WhatsApp goes to school: Mobile instant messaging between teachers and Students. Journal of Information Technology Education Research, 11-19. https://doi.org/10.28945/2051

Bouhnik, D., \& Deshen, M. (2014). WhatsApp goes to school: Mobile instant messaging between teachers and students. Journal of Information Technology Education: Research, 13, 217-231. https://doi.org/10.28945/2051

Boulos, M., Wheeler, S., Tavares, C., \& Jones, R. (2011). How smartphones are changing the face of mobile and participatory healthcare: an overview, with example from eCAALYX. Biomed Eng Online., 10(24). https://doi.org/10.1186/1475-925X-10-24

BusinessofApps. (2020, March 24). WhatsApp Revenue and Usage Statistics (2020). Retrieved from https://www.businessofapps.com/data/: https://www.businessofapps.com/data/whatsapp-statistics/

Cetinkaya, L. (2017). The impact of whatsapp use on success in education process. International Review of Research in Open and Distance Learning, 18(7), 59-74. https://doi.org/10.19173/irrodl.v18i7.3279

Chipunza, P. R. (2013). Using mobile devices to leverage student access to collaboratively generated resources: A case of WhatsApp instant messaging at a South African University. nternational Conference on Advanced Information and Communication Technology for Education.

Church, K., \& de Oliveira, R. (2013). What's up with WhatsApp ?: Comparing Mobile Instant Messaging Behaviors with Traditional SMS. Proc. of the 15th Int. Conf. on Human-Computer Interaction with Mobile Devices and Services (pp. 352-361). ACM. https://doi.org/10.1145/2493190.2493225 
Diaz, J. C., Moro, A. I., \& Carrión, P. V. (2015). Mobile learning: Perspectives. International Journal of Educational Technology in Higher Education, 12(1), 38-49. https://doi.org/10.7238/rusc.v12i1.1944

Echeverria, A., Nussbaum, M., Calderon, J., Bravo, C., \& Infante, C. (2011). Face-to-face collaborative learning supported by mobile phones. Interactive Learning Environment, 19(4), 351-363. https://doi.org/10.1080/10494820903232943

Fattah, S. F. (2015). The Effectiveness of Using a WhatsApp Messenger as One of Mobile Learning Technique to Develop Students' Writing Skills. Journal of Education and Practice, 6(32), 115-127.

Gachago, D., Strydom, S., Hanekom, P., \& Simons, S. (2015). Crossing boundaries: lecturers' perspectives on the use of WhatsApp to support teaching and learning in Higher Education. . Progressio, 37(1), 172-187. https://doi.org/10.25159/0256-8853/579

Gasaymeh, M. (2017). University Students' use of Whatsapp and their Perceptions Regarding its Possible Integration into their Education. Global Journal of Computer Science and Technology, 17(1).

Gon, S., \& Rawekar, A. (2017). Effectivity of E-Learning through Whatsapp as a Teaching Learning Tool. MVP Journal of Medical Sciences, 4(1), 19-25. https://doi.org/10.18311/mvpjms/0/v0/i0/8454

GSMA. (2014). The Mobile economy: Sub-Saharan Africa 2014. Retrieved from http://www.gsma.com: http://www.gsma.com/mobileeconomy/archive/GSMA_ME_SubSaharanAfrica_2014.pdf

Hamidin, N. M. (2015). Penggunaan Aplikasi 'WhatsApp' Dalam Pembelajaran \& Pengajaran (P\&P) di KUIS. !st Global Conference on Technology in Language Learning 2015 (GLIT2015). Kuala Lumpar.

Hui Hsu, H. (2012). The Acceptance of Moodle: An Empirical Study Based on UTAUT. SciRes, 3, 44-46. https://doi.org/10.4236/ce.2012.38B010

Khubyari, L. (2016). Rapport in EFL Classroom with Mobile Application in Everyday Context. International Journal of English Language Education, 4(1), 123-37. https://doi.org/10.5296/ijele.v4i1.8961

Kushwaha, S., \& Jhawar, N. (2018). Role of Whatsapp as a Teaching Aid to Enhance Learning Capabilities of Management Students. Ushus-Journal of Business Management, 17(1), 43-51. https://doi.org/10.12725/ujbm.42.4

La Hanisi, A., Risdiany, R., Dwi Utami, Y., \& Sulisworo, D. (2018). The use of WhatsApp in collaborative learning to improve English teaching and learning process. International Journal of Research Studies in Educational Technology, 29-35. https://doi.org/10.5861/ijrset.2018.3004

Mistar, B. I., \& Embi, A. (2016). Students' perception on the use of WhatsApp as a learning tool in ESL classroom. Journal of Education and Social Sciences, 4.

Moran, M., Hawkes, M., \& Gayar. (2010). Tablet personal computer integration in higher education: Applying the unified theory of acceptance and use technology model to understand supporting factors. Educational Computing Research, 42(1), 79-101. https://doi.org/10.2190/EC.42.1.d

Mwakyusa, P. (2016). Impediments of E-learning Adoption in Higher Learning Institutions of Tanzania: An Empirical Review. Journal of Education and Practice, 7(30), 152-169.

News24. (2020, April 30). Fort Hare University to issue laptops, data as it moves to online learning. Retrieved from https://www.news24.com/SouthAfrica/New:

https://www.news24.com/SouthAfrica/News/lockdown-fort-hare-university-to-issue-laptops-data-as-it-moves-t o-online-learning-20200430

Nikou, A., \& Economides, A. (2017). Mobile-based assessment: Investigating the factors that influence behavioral intention to use. Computers \& Education, 109, 56-73. https://doi.org/10.1016/j.compedu.2017.02.005

Nurazizah, H., Frihatin, Y. L., \& Sugiarto, R. B. (2019). Whatsapp Voice Note in Speaking Class. Journal of English Education and Teaching, 3(3), 343-360. https://doi.org/10.33369/jeet.3.3.343-360

Odendahl, C., \& Springford, J. (2020). Bold policies needed to counter the coronavirus recession. In R. Baldwin, \& B. W. di Mauro, Mitigating the COVID Economic Crisis: Act Fast and Do Whatever It Takes, 145-150. London: CEPR Press.

Patil, A., Shobha, T., Deepthi, M., \& Tadasad, V. (2015). Usage of whatsapp messenger amongst post-graduate students in a university environment: A study of Karnataka state women ${ }^{\text {ee }}$ university, Vijayapura. International Journal of Multidisciplinary Research and Development,, 2(11), 591-594. 
Plana, M. G.-C., Escofet, M. I., Figueras, I. T., Gimeno, A., Appel, C., \& Hopkins, J. (2013). Improving learners' reading skills through instant short messages: A sample study using WhatsApp. 4th World-CALL Conference, 80-84. Glasgow.

Popenici, S. A., \& Kerr, S. (2017). Exploring the Impact of Artificial Intelligence on Teaching and Learning in Higher Education. 12(22), pp. 1-13. Research and Practice in Technology Enhanced Learning, 12(22), 1-13. https://doi.org/10.1186/s41039-017-0062-8

Quah. (2020). Singapore's policy response to COVID-19. In R. Baldwin, \& B. W. di Mauro, Mitigating the COVID Economic Crisis: Act Fast and Do Whatever It Takes, 103-111. London: CEPR Press .

Rambe, P., \& Crispen, C. (2013). Using Mobile Devices to Leverage Student Access tp Collaboratively-generated resources:. Proceedings of the 2013 International Conference on Advanced ICT and Education, 331-337. Atlantis Press. Retrieved from A Case of WhatsApp Instant Messaging, South Africa University.: http://versys.uitm.edu.my/prisma/view/viewPDF.php?pid+48319. https://doi.org/10.2991/icaicte.2013.66

Riaz, A., \& Adnan, A. (2016). Acceptance of tablet apps for e-learning by senior users: A Test of Unified Theory of Acceptance and Use of Technology. Pan-Commonwealth Forum 8 (PCF8), 1-12.

Robles, H., Guerrero, J., Llinás, H., \& Montero, P. (2019). Online teacher- students' interactions using WhatsApp in a law course. Journal of Information Technology Education: Research, 18, 231-252. https://doi.org/10.28945/4321

Salechi, H., \& Ashiyan, Z. (2017). Impact of whatsapp on learning and retention of collocation knowledge among Iranian EFL learners. Advances in language and literary studies., 7(5). https://doi.org/10.7575/aiac.alls.v.7n.5p.112

Saleem, E., Al-Saqri, N., \& Ahmad, A. E. (2016). Acceptance of Moodle as a Teaching/Learning Tool by the Faculty. International Journal of Knowledge Content Development \& Technology of the Department of Information Studies at Sultan Qaboos University, Oman based on UTAUT, 6(2), 5-27. https://doi.org/10.5865/IJKCT.2016.6.2.005

So, S. (2016). Mobile instant messaging support for teaching and learning in Higher Education . Internet and Higher Education , 32-42. https://doi.org/10.1016/j.iheduc.2016.06.001

Sumak, B., Polančič, G., \& Heričko, M. (2010). An empirical study of virtual learning environment adoption using UTAUT. Mobile, Hybrid, and On-Line Learning, 2010, 17-22, IEEE. https://doi.org/10.1109/eLmL.2010.11

TechZim. (2019, March 5). Zimbabwe Now Has The Most Expensive Mobile Data In The World-Report. Retrieved from https://www.techzim.co.zw/2019/03/zimbabwe-now-has-the-most-expensive-data-in-the-world-report/

Tosuntaş, B. S., Karadağ, E., \& Orhan-Özen, S. (2014). The factors affecting Acceptance and Use of interactive whiteboard within the scope of FATIH project: A structural equation model based on the Unified Theory of Acceptance and Use of Technology. Computers \& Education 81. https://doi.org/10.1016/j.compedu.2014.10.009

Venkatesh, V., Morris, M. G., Davis, G. B., \& Davis, F. D. (2003). User acceptance of information technology: Toward a unified view. MIS Quarterly, 27(3), 425-478. https://doi.org/10.2307/30036540

Wits. (2020, April 19). COVID-19 Update 24: Data access: All four major mobile service providers on board. Retrieved from http://www.wits.ac.za/covid19/covid19-news/latest: http://www.wits.ac.za/covid19/covid19-news/latest/covid-19-update-24-data-access-all-four-major-mobile-servi ce-providers-on-board.html

Yeboah, J., \& Dominic, G. (2014). The Impact of WhatsApp Messenger Usage on Students Performance in Tertiary Institutions in Ghana. Journal of Education and Practice, 5(6), 157-164.

Yulius, S. I., \& Hartanto, R. (2016). The effect of modelation of vocational school to online learning on Sahid Sukarta University. JOURNAL OF Applied Science and Technology Research of Applied Science and Education, 10(4), 218-224. https://doi.org/10.22216/jit.2016.v10i4.534

Zengin, B., Arikan, A., \& Dogan, D. (2011). Opinions of English Major Students about Their Departments' Websites. Contemporary Educational Technology, 2(4), 294-307. https://doi.org/10.30935/cedtech/6060

Zimstats. (2014). Information and Communication Technology Household Survey. Harare. 